\title{
The first second-generation adenosine drug enters the US market
}

\author{
Amir Pelleg • Luiz Belardinelli
}

Published online: 20 June 2008

(C) Springer Science + Business Media B.V. 2008

On 10 April 2008, CV Therapeutics, Inc. of Palo Alto, California, USA, received approval from the US Food and Drug Administration (FDA) for the use of Lexiscan ${ }^{\circledR}$ (regadenoson; CVT-3146), an $\mathrm{A}_{2 \mathrm{~A}}$ adenosine receptor $\left(\mathrm{A}_{2 \mathrm{~A}} \mathrm{AdoR}\right)$ agonist, as a pharmacological stress agent in conjunction with radionuclide myocardial perfusion imaging (MPI) in patients unable to undergo adequate exercise stress.

Lexiscan ${ }^{\circledR}$ has a higher affinity for $\mathrm{A}_{2 \mathrm{~A}}$ adenosine receptors than adenosine and is a more potent coronary vasodilator. It preferentially dilates coronary arteries relative to other vascular beds [1], probably due to the high density of $\mathrm{A}_{2 \mathrm{~A}} \mathrm{AdoR}$ in the coronary arteries and high receptor reserve at that site [2], resulting in maximal vasodilation induced by the activation of a small percentage of these receptors.

MPI is commonly used in the clinical setting for the diagnosis of coronary artery stenosis. The rationale for the use of pharmacologic vasodilators in MPI is based on the differential blood flow response in normal vs. diseased coronary arteries, resulting in a coronary-steal phenomenon. The production of myocardial perfusion defects is

\author{
A. Pelleg $(\square)$ \\ Department of Medicine, Drexel University College of Medicine, \\ M.S. \#470, $245 \mathrm{~N}^{\text {th }}$ Street, \\ Philadelphia, PA 19102-1192, USA \\ e-mail: apelleg@drexelmed.edu \\ L. Belardinelli \\ CV Therapeutics, Inc., \\ 1651 Page Mill Road, \\ Palo Alto, CA 94304, USA \\ e-mail: Luiz.Belardinelli@cvt.com
}

reflected in nonhomogeneous distribution of a radiopharmaceutical, which is administered subsequent to the vasodilator agent, detected by a gamma camera, and quantified by a computer utilizing specific software. Adenosine and dipyridamole (an adenosine transport blocker that elevates extracellular adenosine levels) have previously been used as pharmacologic stressors; however, the use of both is associated with adverse effects caused by the activation of $A_{1} A d o R$ in addition to the $A_{2 A} A d o R$. For example, first-degree atrioventricular (AV) block occurs in approximately $10 \%$ and second- or third-degree AV block in approximately $4 \%$ of patients due to the inhibitory effect of adenosine on the AV nodal conduction [3].

Lexiscan ${ }^{\circledR}$ (Fig. 1), given as a bolus injection, increases coronary blood flow velocity by more than 2.5 -fold above baseline for at least $2 \mathrm{~min}$ [4], which is ample time for the administration and distribution of a radiopharmaceutical.

Experience with regadenoson (Lexiscan ${ }^{\circledR}$ ) has shown that it is well-tolerated, as effective as adenosine as a pharmacologic stressor in MPI, and associated with less side effects than adenosine [5]. Lexiscan ${ }^{\circledR}$ is approved 19 and 13 years after the approval of Adenocard ${ }^{\circledR}$ (intravenous adenosine) in 1989 for conversion of paroxysmal supraventricular tachycardia (PSVT) to sinus rhythm and Adenoscan ${ }^{\circledR}$ in 1995 as a pharmacological stress agent in MPI, respectively. The approval of Lexiscan ${ }^{\circledR}$ represents an important milestone in the adenosine research field. It is the first synthetic adenosine receptor ligand approved for medical use. The approval should serve as an impetus for the development of others adenosine and purine nucleotide analogs as novel diagnostic and therapeutic agents. 
Fig. 1 Lexiscan ${ }^{\circledR}($ CVT-3146):

Adenosine, 2-[4-[(methylamino) carbonyl]-1H-pyrazol-1-yl]-, monohydrate

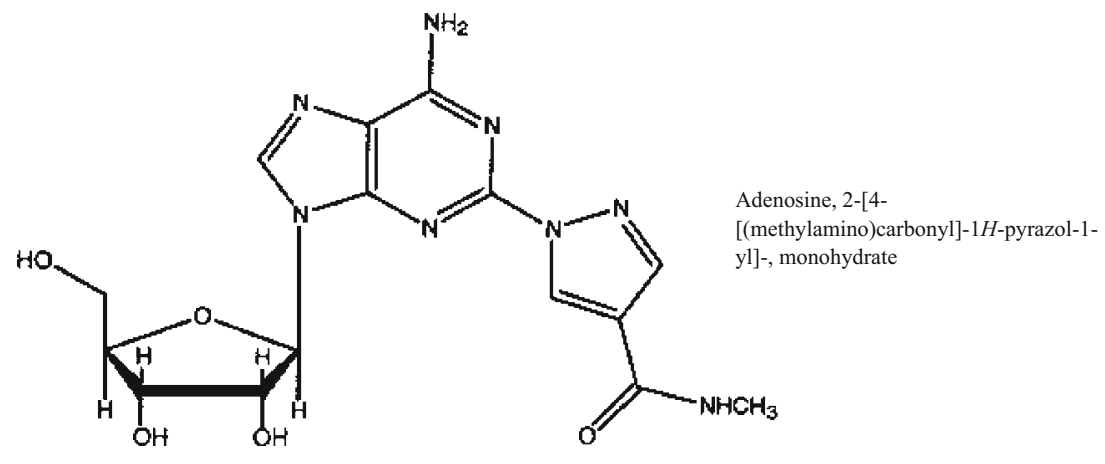

Disclosure Dr. Pelleg and his colleagues performed several preclinical studies with CVT-3146 on a contractual basis; they have never held any type of securities issued by CV Therapeutics. Dr. Belardinelli is senior vice president at $\mathrm{CV}$ Therapeutics.

\section{References}

1. Dhalla AK, Xu J, Kussmaul W, Kurnik PP, Pelleg A, Belardinelli L (2004) Differential vasodilatory effects of CVT-3146, an $\mathrm{A}_{2 \mathrm{~A}}$ adenosine receptor agonist, in various vascular beds in anesthetized dogs. J Am Coll Cardiol 43:367A
2. Shryock JC, Snowdy S, Baraldi PG, Cacciari B, Spalluto G, Monopoli A, Ongini E, Baker SP, Belardinelli L (1998) A2Aadenosine receptor reserve for coronary vasodilation. Circulation 98:711-718

3. Verani MS (1991) Pharmacological stress with adenosine for myocardial perfusion imaging. Semin Nucl Med 21:266-272

4. Trochu JN, Zhao G, Post H, Xu X, Belardinelli L, Belloni FL, Hintze TH (2003) Selective A2A adenosine receptor agonist as a coronary vasodilator in conscious dogs: potential for use in myocardial perfusion imaging. J Cardiovasc Pharmacol 41:132-139

5. Lieu HD, Shryock JC, von Mering GO, Gordi T, Blackburn B, Olmsted AW, Belardinelli L, Kerensky RA (2007) Regadenoson, a selective A2A adenosine receptor agonist, causes dose-dependent increases in coronary blood flow velocity in humans. J Nucl Cardiol $14: 514-520$ 